Article history

Received February 16, 2021

Accepted December 29, 2021

\title{
PENERAPAN METODE KLUSTERING FUZZY C-MEANS UNTUK PENENTUAN PEMINATAN PEMILIHAN JURUSAN PADA SEKOLAH MENENGAH TINGKAT ATAS
}

\author{
Heru Kartika Candra, Muhammad Bahit, Billy Sabella \\ Komputerisasi Akuntansi, Politeknik Negeri Banjarmasin, Indonesia \\ Email: heru_kcandra@poliban.ac.id; bahit@poliban.ac.id; billy.sabella@akuntansipoliban.ac.id
}

\begin{abstract}
Determination of majors for students in accordance with the weight of knowledge conditions or commonly referred to as determining student majors in the high school environment is determined by the understanding of learning in understanding knowledge which is supported by elements of specialization, because the scientific character is proportional to the same properties of the object pursuing the science. With this assumption, someone who studies a science will be able to deepen it if he has pleasure in what he is studying. Pleasure with something being learned can affect the quality of student learning outcomes in certain scientific fields of study. It can be said that the focus on a material being studied, students will learn more comfortably and achieve a better understanding so that the weight of the knowledge learned will be achieved [1]. The process of determining the majors is held to select and classify the same students' abilities in one education department according to the field taken. This is done so that there is an adjustment to the students' interests and abilities in the desired field of majors, so that it is expected to provide comfort in learning and affect the achievement of understanding and student learning achievement. The formation of data grouping is one of the methods or methods used in parsing uniform patterns in data. Grouping analysis is the process of sorting data in a group into several groups whose data similarity in one group is greater than the similarity of the data to data in other groups [4]. A method that is often used in data set grouping is the use of the clustering algorithm [5]. There are many data clustering algorithms, one of which is frequently used, namely Fuzzy C-Means. The K-Means clustering method is not appropriate to use to classify students based on the similarity of academic abilities in the process of determining majors according to the provisions of the Ministry of National Education. Of the 42 examples, some of the data are 10 Banjarmasin Public Senior High Schools 13 which will be grouped into 3 groups based on the similarity in the value of 10 core majors. The difference between the results of clustering student data manually (based on the provisions used in SMA 13 Banjarmasin) with the results of the K-Means algorithm clustering is due to (a) the K-Means algorithm performs student data clustering based on similar data patterns (scores) in groups that are which has been set, and is not tied to a certain rule or variable values. (b) The student clustering method used in SMA 13 Banjarmasin in determining majors is grouping students based on the similarity of values in predetermined groups, but tied to a certain rule or variable value, namely the minimum standard value (minimum completeness criteria value / KKM). ) to belong to a certain group.
\end{abstract}

Keywords: Senior High School Passing; Fuzzy K-Means; KKM 


\begin{abstract}
Abstrak
Penentuan jurusan untuk siswa sesuai dengan kondisi bobot pengetahuan atau biasa disebut dengan penentuan jurusan siswa di lingkungan SMA ditentukan oleh pemahaman pembelajaran dalam memahami pengetahuan yang didukung oleh unsur-unsur peminatan, karena karakter keilmuan sebanding dengan sifat yang sama dari obyek yang menekuni keilmuan tersebut. Dengan asumsi tersebut seseorang yang mendalami suatu keilmuan akan dapat mendalaminya apabila mempunyai kesenangan terhadap apa yang sedang dipelajarinya. Rasa senang akan sesuatu yang dipelajari dapat mempengaruhi mutu capaian hasil belajar siswa dalam keilmuan bidang studi tertentu. Hal ini dapat dikatakan bahwa fokus terhadap suatu materi yang dipelajari, siswa akan belajar lebih nyaman dan mencapai pemahaman yang lebih baik sehingga akan tercapai bobot keilmuan yang dipelajari [1]. Proses penentuan jurusan diadakan untuk memilih dan mengklasifikasikan kemampuan siswa yang sama dalam satu jurusan Pendidikan sesuai bidang yang ditempuh. Hal ini dilakukan agar adanya penyesuaian terhadap peminatan dan kemampuan siswa dalam bidang jurusan yang diinginkan, sehingga diharapkan dapat memberikan kenyamanan dalam belajar dan berpengaruh dalam pencapaian pemahaman dan prestasi siswa belajar. Pembentukan pengelompokan data merupakan salah satu metode atau cara yang dipakai dalam mengurai pola yang seragam dalam suatu data. Analisa pengelompokan merupakan proses memilah-milah data dalam suatu kelompok ke dalam beberapa kelompok yang kemiripan datanya dalam suatu kelompok lebih besar daripada kemiripan data tersebut dengan data dalam kelompok lain[4]. Suatu cara yang sering dipakai dalam pengelompokan data set yaitu dengan pemakaian algoritma Clustering [5]. Terdapat banyak algoritma klastering data, salah satu yang sering dipakai yaitu Fuzzy C-Means. Metode klastering $K$ Means kurang tepat digunakan untuk mengelompokkan siswa berdasarkan kesamaan kemampuan akademisi dalam proses penentuan jurusan menurut ketentuan Departemen Pendidikan Nasional. Dari 42 contoh sebagian data 10 Sekolah Menengah Atas Negeri 13 Banjarmasin yang akan dikelompokkan dalam 3 kelompok berdasarkan kesamaan nilai 10 mata pelajaran inti penjurusan. Perbedaan hasil pengklasteran data siswa secara manual (berdasarkan ketentuan yang di gunakan di SMA 13 Banjarmasin) dengan hasil pengklasteran algoritma K-Means disebabkan karena (a) Algoritma K-Means melakukan pengklasteran data siswa berdasarkan kemiripan pola data (nilai) dalam kelompok-kelompok yang yang telah ditetapkan, dan tidak terikat pada suatu aturan atau nilai-nilai variabel tertentu. (b) Metode pengklasteran siswa yang digunakan di SMA 13 Banjarmasin dalam penentuan jurusan yaitu mengelompokkan siswa berdasarkan kesamaan nilai dalam kelompok-kelompok yang telah ditetapkan, tetapi terikat pada suatu aturan atau nilai variabel tertentu, yaitu nilai standar minimum (nilai Kriteria Ketuntasan Minimum / KKM) untuk masuk pada kelompok tertentu.
\end{abstract}

Kata Kunci : Penjurusan SMA; Fuzzy K-Means; KKM 


\section{PENDAHULUAN}

Dalam proses belajar di SMA, selain proses pembelajaran materi pengetahuan perlu juga adanya perhatian terhadap siswa-siswa berkaitan dengan kemampuan dan peminatan bidang yang ditonjolkan oleh masing-masing siswa. Setiap siswa mempunyai kemampuan masing-masing baik itu perbedaan dalam hal kemampuan kognitif atau motivasi dalam hal prestasi, peminatan dan kreativitas. Melihat perbedaan kemampuan yang dimiliki siswa, maka tujuan belajar di sekolah tidak hanya dalam proses pendidikan, akan tetapi meliputi pembimbingan, pengarahan serta penempatan siswa sesuai dengan peminatan dan kemampuan yang dimiliki, sistem pembelajaran yang sesuai dan strategi mengajar yang disesuaikan dengan pemintatan individu siswa. Kemungkinan dampak yang ditimbulkan apabila terjadinya kesalahan dalam penempatan yang tidak sesuai dengan peminatan yang dimiliki siswa adalah rendahnya prestasi belajar siswa [1]. Berdasarkan hal tersebut sudah seharusnya manajemen pemangku pendidikan di SMA harus lebih fokus terhadap kondisi siswa dalam mengembangkan potensi diri siswa.

Penentuan jurusan untuk siswa disesuaikan dengan kondisi bobot pengetahuan atau biasa disebut dengan pemahaman pembelajaran dalam memahami pengetahuan yang didukung oleh unsur-unsur peminatan, karena karakter keilmuan sebanding dengan sifat yang sama dari obyek yang menekuni ilmu tersebut. Rasa senang akan sesuatu yang dipelajari dapat mempengaruhi mutu capaian hasil belajar siswa dalam keilmuan bidang studi tertentu. Hal ini dapat dikatakan bahwa fokus terhadap suatu materi yang dipelajari, siswa akan belajar lebih nyaman dan mencapai pemahaman yang lebih baik sehingga akan tercapai bobot keilmuan yang dipelajari [1].

Peraturan yang berlaku pada Sekolah SMA khususnya pada siswa kelas $\mathrm{X}$ apabila naik ke klas XI, maka adanya proses pengelompokan peminat ditandai dengan pemilihan jurusan bidang yang diminati dan wadah pengembangan karakter individu siswa. Jurusan di SMA terdiri dari IPA, IPS, dan Bahasa. Salah satu pertimbangan untuk menyeleksi siswa dalam menentukan jurusan adalah prestasi siswa pada semester satu dan dua (kelas X) dalam bentuk nilai mata pelajaran [1].

Proses penentuan jurusan diadakan untuk memilih dan mengklasifikasikan kemampuan siswa yang sama dalam satu jurusan Pendidikan sesuai bidang yang ditempuh. Hal ini dilakukan agar adanya penyesuaian terhadap peminatan dan kemampuan siswa dalam bidang jurusan yang diinginkan, sehingga diharapkan dapat memberikan kenyamanan dalam belajar dan berpengaruh dalam pencapaian pemahaman dan prestasi siswa belajar. Dengan dasar kemampuan siswa yang sama diharapkan dalam proses belajar dapat berjalan dengan lancar dan meningkatkan minat dan prestasi belajar. Pembentukan pengelompokan data merupakan salah satu metode atau cara yang dipakai dalam mengurai pola yang seragam dalam suatu data. Analisa pengelompokan merupakan proses memilahmilah data dalam suatu kelompok ke dalam beberapa kelompok yang kemiripan datanya dalam suatu kelompok lebih besar daripada kemiripan data tersebut dengan data dalam kelompok lain[4]. Suatu cara yang sering dipakai dalam pengelompokan data set yaitu dengan pemakaian algoritma Clustering [5].

\section{METODE PENELITIAN}

Secara umum metode penelitian mengacu pada kerangka pemikiran seperti pada gambar 1 .

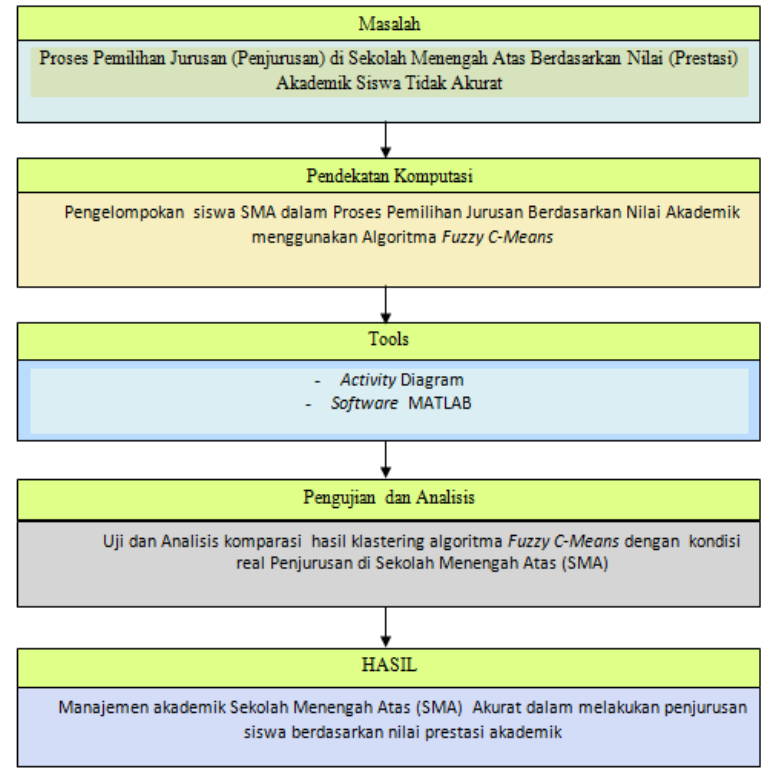

Gambar 1. Skema Kerangka Pemikiran 
1. Inisiasasi Permasalahan

Merupakan kegiatan pertama yang dilakukan untuk analisa permasalahan dalam proses pengelompokan siswa SMA berdasarkan nilai prestasi akademik dalam proses pemilihan jurusan.

2. Perancangan dalam pembahasan Masalah Merupakan tahapan dalam menentukan metode yang tepat dalam pembahasan masalah merunut dari kajian pustaka. Metode Algoritma Fuzzy C Means, yang sudah banyak digunakan dalam penelitian untuk kasus pengelompokan data, akan diterapkan dalam pengelompokan data nilai prestasi siswa untuk menentukan jurusan siswa yang sesuai.

3. Pembahasan dan pengujian serta analisis hasil

Merupakan tahap proses pengujian hasil kelompok metode Fuzzy C-Means yang dierapkan dalam mengelompokan data siswa SMA berdasarkan nilai prestasi akademik untuk proses penjurusan, dengan data traning berupa data nilai prestasi akademik siswa kelas X. Hasil penerapan metode Fuzzy C-Means diuji dengan uji banding terhadap kondisi real hasil Penjurusan di SMA.

4. Kesimpulan hasil penelitian

Sampel data yang dipergunakan adalah data nilai sebelum dan setelah peminatan siswa di SMA Negeri 13 Banjarmasin angkatan tahun 2009 sebanyak 42 orang dari total 129 siswa. Jumlah sampel ini di dasarkan pada metode pengambilan sampel menggunakan Nomorgram Harry King untuk menentukan ukuran sampel dari populasi sampai 2.000 [13]. Tingkat kesalahan penetapan jumlah sampel dalam metode ini ini adalah sekitar $10 \%$. Parameter data yang dipergunakan dalam eksperimen adalah rata-rata nilai mata pelajaran kelompok peminatan. Untuk jurusan IPA dipergunakan mata pelajaran Biologi, Matematika, Fisika dan Kimia. Untuk jurusan IPS dipergunakan mata pelajaran Sosiologi, Geografi, Sejarah dan Ekonomi. Sedangkan untuk jurusan Bahasa dipergunakan Bahasa Inggris dan Bahasa Indonesia. Sampel data selengkapnya dapat dilihat pada Gambar 2 dan Gambar 3.

\begin{tabular}{|c|c|c|c|c|c|c|c|c|c|c|}
\hline \multirow{2}{*}{ Siswa } & \multicolumn{10}{|c|}{ Mata Pelajaran dan Nilai } \\
\hline & P1 & P2 & P3 & P4 & P5 & P6 & P7 & P8 & pg & P10 \\
\hline 1 & 75,0 & 77,2 & 69,6 & 67,3 & 75,3 & 68,9 & 85,0 & 70,3 & 75,2 & 77,9 \\
\hline 2 & 80,1 & 70,0 & 69,2 & 80,3 & 77,5 & 70,8 & 80,5 & 77,2 & 65,8 & 68,8 \\
\hline 3 & 70,5 & 92,0 & 77,5 & 70,0 & 66,9 & 75,0 & 72,5 & 68,1 & 69,3 & 80,0 \\
\hline 4 & 68,5 & 66,2 & 62,5 & 75,0 & 77,5 & 80,3 & 75,0 & 75,5 & 80,5 & 75,0 \\
\hline 5 & 78,5 & 85,0 & 70,3 & 72,5 & 69,0 & 65,8 & 85,0 & 65,3 & 75,3 & 77,0 \\
\hline 6 & 75,0 & 70,5 & 82,0 & 85,3 & 72,5 & 85,5 & 75,0 & 72,5 & 60,0 & 69,2 \\
\hline 7 & 67,0 & 69,2 & 75,0 & 70,5 & 67,9 & 85,0 & 70,3 & 75,0 & 75,5 & 70,3 \\
\hline 8 & 85,0 & 70,3 & 75,5 & 70,5 & 75,0 & 75,8 & $\$ 2,5$ & 67,5 & 69,3 & 68,2 \\
\hline 9 & 70,5 & 80,3 & 72,5 & $\$ 5,0$ & 75,0 & 66,9 & 67,5 & 85,3 & 92,5 & 68,5 \\
\hline 10 & 90,3 & 65,9 & 60,5 & 69,3 & 75,0 & 85,3 & 75,0 & 75,0 & 85,5 & 70,0 \\
\hline 11 & 70,0 & 80,5 & 70,5 & 75,0 & 80,0 & 69,3 & 62,5 & 67,5 & 85,5 & 75,0 \\
\hline 12 & 75,0 & 70,5 & 70,3 & 75,5 & 82,5 & 75,0 & 85,8 & 70,5 & 70,8 & 68,8 \\
\hline 13 & 68,5 & 75,8 & 70,5 & 80,0 & 69,5 & 80,3 & 75,5 & 70,5 & 67,3 & 75,5 \\
\hline 14 & 80,3 & 66,5 & 75,0 & 70,5 & 80,5 & 69,5 & 75,3 & 70,5 & 75,5 & 69,6 \\
\hline 15 & 75,0 & 70,0 & 67,3 & 75,5 & 75,0 & 70,5 & 69,2 & 78,3 & 67,8 & $\$ 2,0$ \\
\hline 16 & 75,0 & 75,0 & 80,5 & 66,9 & 75,0 & 70,0 & 80,5 & 67,3 & 75,0 & 65,5 \\
\hline 17 & 75,3 & 77,5 & 85,0 & 75,5 & 82,5 & 75,5 & 78,6 & 80,3 & 75,5 & 82,5 \\
\hline 18 & $\$ 2,5$ & 68,2 & 70,5 & 65,9 & 82,5 & 70,5 & 69,2 & 75,0 & 80,5 & 75,3 \\
\hline 19 & 69,5 & 75,0 & 85,0 & 66,9 & 75,0 & 68,5 & 85,0 & 72,5 & 85,0 & 75,5 \\
\hline 20 & 75,5 & 70,5 & 80,3 & 72,5 & 69,0 & 65,3 & 75,0 & 80,5 & 75,8 & 68,5 \\
\hline 21 & 75,5 & 75,0 & 70,5 & 75,0 & 75,0 & 75,8 & 69,0 & 65,3 & 68,8 & 75,0 \\
\hline 22 & 69,0 & 80,5 & 67,3 & 65,5 & 75,5 & 80,5 & 72,8 & 85,0 & 80,8 & 72,5 \\
\hline 23 & 70,8 & $\$ 2,3$ & 75,5 & 78,5 & 79,5 & 85,3 & 77,5 & 72,3 & 76,5 & 70,5 \\
\hline 24 & 75,3 & 70,5 & 80,3 & 75,3 & 69,0 & $\$ 2,9$ & 67,3 & 65,5 & 80,3 & 75,0 \\
\hline 25 & 80,2 & 68,5 & 75,2 & 80,5 & 72,9 & 70,9 & 65,5 & 80,3 & 67,5 & 77,3 \\
\hline 26 & 75,0 & 75,2 & 72,5 & 60,0 & 75,5 & 80,5 & 90,3 & 69,5 & 72,8 & 65,3 \\
\hline 27 & 72,0 & 82,5 & 87,2 & 92,0 & 81,3 & 77,2 & 70,5 & 75,5 & 77,3 & 80,3 \\
\hline 28 & 60,0 & $\$ 2,5$ & 75,0 & 65,5 & 70,5 & 77,9 & $\$ 2,2$ & 75,8 & 75,5 & $\$ 2,5$ \\
\hline 29 & 90,2 & 70,5 & 75,2 & 77,5 & 62,5 & 85,5 & 78,5 & 75,5 & 90,3 & 70,2 \\
\hline 30 & 77,9 & 70,9 & 75,5 & 82,5 & 75,0 & 77,9 & 77,3 & 75,5 & 62,5 & 85,0 \\
\hline 31 & 62,5 & 75,5 & 72,2 & 87,5 & $\$ 1,5$ & 77,9 & 75,3 & 82,7 & 87,6 & $\$ 4,5$ \\
\hline 32 & 79 & 82,5 & 87,5 & 72,5 & 72,5 & 75 & $\$ 8,6$ & 70,5 & 72,5 & 85 \\
\hline 33 & 60,5 & 72,5 & 62,5 & 70,5 & 82,5 & 67,5 & 71,5 & 62,5 & 70,5 & 72,2 \\
\hline 34 & 77,8 & 60,1 & 65,6 & 73,4 & 77,8 & 70,5 & 79,5 & 77,6 & 75,2 & 62,8 \\
\hline 35 & 85,2 & 77,9 & 85 & 82,5 & 89,5 & 94,5 & 80,7 & 79,5 & 77,8 & $\$ 2,1$ \\
\hline 36 & 69,5 & 78,6 & 77,5 & 75,5 & 70,5 & 77,5 & 65,4 & 80,6 & 70,5 & 72,5 \\
\hline 37 & 91,4 & $\$ 1,6$ & 77,6 & 79,4 & 75,6 & 88,7 & 80 & 72,8 & 67 & 74,5 \\
\hline 38 & 65,5 & 69,7 & 71,5 & 70,5 & 65 & 72,5 & 77,2 & 68,5 & 72,5 & 75 \\
\hline 39 & 75,5 & 72 & 75 & 87,5 & 75,5 & 82,5 & 85 & 79,5 & 75 & 80,7 \\
\hline 40 & 65 & 70,2 & 64,5 & 70.5 & 74,5 & 79,5 & 72,5 & 75,5 & 70,9 & 75 \\
\hline 41 & 90,2 & 75,8 & 80,1 & 75 & 75 & 78,2 & 80,1 & 69,4 & 70,6 & 78,9 \\
\hline 42 & 74,5 & 72 & 69,7 & 65 & 75 & 70,9 & 78,5 & 72,5 & 65 & 72 \\
\hline
\end{tabular}

Sumber: Database Akademik SMA Negeri 13 Banjarmasin, 2011.

Gambar 2. Sampel Data Nilai Siswa Angkatan 2008 SMA Negeri 13 Banjarmasin Tahun 2010 (Sebelum Peminatan).

Keterangan Mata Pelajaran:

P1 : Biologi P6 : Geografi

P2 : Matematika IPA P7 : Sejarah

P3 : Fisika P8 : Ekonomi

P4 : Kimia P9 : Bahasa Inggris

P5 : Sosiologi P10: Bahasa Indonesia 


\begin{tabular}{|c|c|c|c|}
\hline \multirow[t]{2}{*}{ Siswa } & \multirow[t]{2}{*}{ Peminatan } & \multicolumn{2}{|c|}{$\begin{array}{l}\text { Nal Rata-rata } \\
\text { Peminatan }\end{array}$} \\
\hline & & $\mathrm{K})_{3} \mathrm{XI}$ & $\mathrm{K} 13 \mathrm{XII}$ \\
\hline 1 & Bahas a & 70,2 & 75,2 \\
\hline 2 & IPS & 77,0 & 75,5 \\
\hline 3 & IPA & 75,5 & 78,0 \\
\hline 4 & Bahasa & 72,0 & 74,5 \\
\hline 5 & IPA & 75,8 & 75,5 \\
\hline 6 & IPA & 71,5 & 74,5 \\
\hline 7 & IPS & 69,0 & 65,5 \\
\hline 8 & IPA & 70.5 & 72.5 \\
\hline 9 & Bahssa & 76,3 & 75,5 \\
\hline 10 & Bahssa & 74,5 & 72,5 \\
\hline 11 & Bahssa & 72,5 & 70.0 \\
\hline 12 & IPS & 85.2 & 80,5 \\
\hline 13 & IPS & 81,5 & $S S, 0$ \\
\hline 14 & IPS & 77,5 & 75,0 \\
\hline 15 & Bahasa & 69,5 & 75,5 \\
\hline 16 & IPA & 74,3 & 71,3 \\
\hline 17 & IPS & 80,7 & 82,5 \\
\hline 18 & Bahasa & 74,0 & 70,5 \\
\hline 19 & Bahssa & 71,5 & 72,5 \\
\hline 20 & IPA & 74,0 & 71,0 \\
\hline 21 & IPA & 69,5 & 73.5 \\
\hline 22 & IPS & 82,5 & 79,5 \\
\hline 23 & IPS & 72,5 & 70,8 \\
\hline 24 & Bahasa & 65,5 & 70,5 \\
\hline 25. & IPA & 76,0 & 78,3 \\
\hline 26 & IPS & 78.0 & 76,5 \\
\hline 27 & IPA & 72,5 & 71,0 \\
\hline 28 & Bahasa & 71,0 & 67,5 \\
\hline 29. & Bahasa & $\$ 2,0$ & $\mathrm{so}, 0$ \\
\hline 30 & IDA & 72,5 & 67,8 \\
\hline 31. & Bahasa & 75,9 & 77,5 \\
\hline 32. & IPA & 80,7 & 75,5 \\
\hline 33 & Bahasa & 70,5 & 68,5 \\
\hline 34. & IPS & 82,8 & 80,5 \\
\hline 35 & IPS & 73,5 & 71,5 \\
\hline 36. & IPA & 78,2 & 75,5 \\
\hline 37 & IPA & 74,5 & 72,0 \\
\hline 38 & Bahasa & 69,0 & 71,3 \\
\hline 39. & IPS & 70,7 & 72,0 \\
\hline 40. & IPS & 77,5 & 69,5 \\
\hline 41 & IPA & 70,3 & 79,5 \\
\hline 42 & IPS & 72,8 & 75,3 \\
\hline
\end{tabular}

Sumber: Database Akademik SMAN 13 Banjarmasin, 2011.

Gambar 3. Sampel Data Nilai Rata-rata Bidang Peminatan Siswa Angkatan 2009 SMA Negeri 13 Banjarmasin Tahun 2010 (Setelah Peminatan)

\section{HASIL DAN PEMBAHASAN}

Pada tahap selanjutnya ditentukan nilai bidang minat tertentu yang diperoleh dari hasil perhitungan rata-rata mata pelajaran peminatan yang berada dalam kelompok bidang minat tersebut sebelum dilakukan peminatan. Data ini dipergunakan sebagai data parameter ujicoba peminatan menggunakan FCM, seperti yang terlihat pada Gambar 4.

\begin{tabular}{|c|c|c|c|}
\hline \multirow{2}{*}{ Siswa } & \multicolumn{3}{|c|}{ Nilai Rata-rata Peminatan } \\
\hline & IPA & IPS & Bahasa \\
\hline 1 & 722 & 74.8 & 76.5 \\
\hline 2 & 749 & 76,5 & 67,3 \\
\hline 3 & 775 & 70.6 & 74,6 \\
\hline 4 & 68.1 & 77,1 & 77,8 \\
\hline 5 & 76.6 & 71,3 & 76,1 \\
\hline 6 & 782 & 76.4 & 64,6 \\
\hline 7. & 70.4 & 745 & 72.9 \\
\hline 8 & 753 & 752 & 68.7 \\
\hline 9 & 77.1 & 73.7 & 80.5 \\
\hline 10 & 77.5 & 77.6 & 77.8 \\
\hline 11 & 74.0 & 69.8 & 80,3 \\
\hline 12 & 72,8 & 78,4 & 69,8 \\
\hline 13 & 73.7 & 739 & 71.4 \\
\hline 14 & 73.1 & 739 & 72.5 \\
\hline 15 & 71.9 & 73,2 & 74,9 \\
\hline 16 & 743 & 732 & 70,3 \\
\hline 17 & 783 & 792 & 79,0 \\
\hline 18 & 71.8 & 743 & 77,9 \\
\hline 19 & 74.1 & 753 & 80.3 \\
\hline 20 & 74.7 & 72,4 & 72,1 \\
\hline 21 & 74.0 & 713 & 71,9 \\
\hline 22 & 70,6 & 78,5 & 76,6 \\
\hline 23 & 76.8 & 78.6 & 73.5 \\
\hline 24 & 753 & .712. & 77,6 \\
\hline 25 & 76,1 & 72,4 & 72,4 \\
\hline 26 & 70,7 & 789 & 69,0 \\
\hline 27 & 83,4 & 76.1 & 78.8 \\
\hline 28 & 70.8 & 76.6 & 79,0 \\
\hline 29 & 783 & 75,5 & 80,2 \\
\hline 30 & 76,7 & 76.4 & 73.8 \\
\hline 31 & 744 & 79.4 & 86,1 \\
\hline 32 & 80,4 & 76,7 & 78,8 \\
\hline 33 & 66.5 & 71,0 & 71,4 \\
\hline 34 & 692 & 76,4 & 69,0 \\
\hline 35 & 82,7 & 86,1 & 80,0 \\
\hline 36 & 75,3 & 73,5 & 71,5 \\
\hline 37 & 82,5 & 79,3 & 70,8 \\
\hline 38 & 69,3 & 70,8 & 73,8 \\
\hline 39 & 77,5 & 80,6 & 77,9 \\
\hline 40 & 67,6 & 75,5 & 73,0 \\
\hline 41 & 80,3 & 75,7 & 74,8 \\
\hline 42 & 70,3 & 74,2 & 68,5 \\
\hline
\end{tabular}

Gambar 4. Data Mentah 
Setelah variabel data sumber peminatan diketahui, selanjutnya dilakukan pemetaan data mengikuti algoritma FCM:

1. Menetapkan matriks partisi awal $U$ berupa matriks berukuran $\mathrm{n} \times \mathrm{m}$

$\mathrm{n}$ : jumlah sampel data, yaitu $=42$

$\mathrm{m}$ : parameter/atribut setiap data, yaitu $=3$

$\mathrm{Xij}=$ data sampel ke-i $(\mathrm{i}=1,2, \ldots, \mathrm{n})$, atribut ke-j $(j=1,2, \ldots, m)$.

Data untuk matriks partisi awal yang digunakan adalah data pada tabel 3 .

2. Menentukan Nilai Parameter Awal :

- Jumlah cluster (c) $=3$

- Pangkat $(\mathrm{w})=2$

- Maksimum interasi (MaxIter) $=100$

- Error terkecil yang diharapkan $(\xi)=10^{-5}$

- Fungsi objektif awal $\left(\mathrm{P}_{0}\right)=0$

- Interasi awal $(\mathrm{t})=1$

3. Membangkitkan bilangan random $\mu$ ik, $\mathrm{i}=1,2, \ldots, \mathrm{n} ; \mathrm{k}=1,2, \ldots \mathrm{c}$; sebagai elemen-elemen matriks partisi awal U.

Matrik partisi awal $\left(\mathrm{u}_{1}\right)$ secara random yang terbentuk dengan menggunakan Matlab adalah:

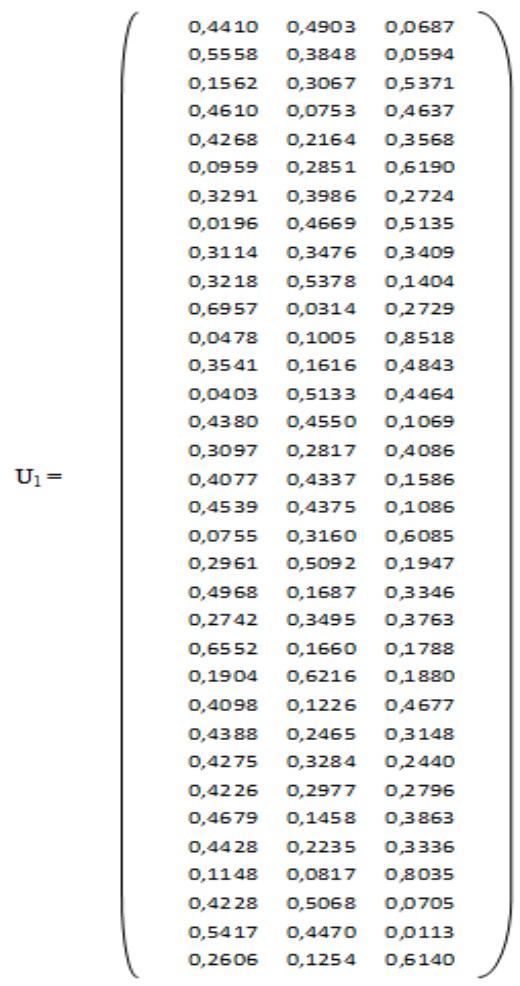

Gambar 5. Matriks partisi awal

\section{Menentukan Pusat Klaster V}

Pada iterasi pertama, dengan menggunakan persamaan 1:

$$
V_{k j}=\frac{\sum_{i=1}^{42}\left(\left(\mu_{i k}\right)^{2} * X_{i j}\right)}{\sum_{i=1}^{42}\left(\mu_{i k}\right)^{2}}
$$

\begin{tabular}{|c|c|c|c|c|c|c|c|c|}
\hline \multirow{2}{*}{ Sma } & \multirow{2}{*}{\begin{tabular}{|l|}
$\begin{array}{l}\text { Derajat } \\
\text { Keangpotaan } \\
\text { Pada Klaster ke-1 }\end{array}$ \\
$(\mu i 1)$
\end{tabular}} & \multicolumn{3}{|c|}{ Data yang diklaster } & \multirow{2}{*}{$(\mu i 1)^{2}$} & \multirow{2}{*}{$(\mu \mathrm{i} 1)^{2} \times \mathrm{X} \mid 1$} & \multirow{2}{*}{$(\mu i 1)^{2} \times x \mid 2$} & \multirow{2}{*}{$(\mu i 1)^{2} \times X 13$} \\
\hline & & $\mathrm{x} 11$ & $\mathrm{x} 12$ & $\mathrm{x}_{13}$ & & & & \\
\hline 1 & $\begin{array}{r}0,4410 \\
\end{array}$ & 72,2 & 74,8 & 76,5 & 0,1945 & 14,0 & 14,6 & 149 \\
\hline 2 & 0,5558 & 749 & 76,5 & 67,3 & 0,3089 & 23,1 & 23,6 & 20,8 \\
\hline 3 & 0,1562 & 77,5 & 70,6 & 74,6 & 0,0244 & 1,9 & 1,7 & 1,8 \\
\hline 4$]$ & 0,4610 & 68,1 & 77,1 & 77,8 & 0,2125 & 14,5 & 16,4 & 16,5 \\
\hline 5 & 0,4268 & 76,6 & 71,3 & 76,1 & 0,1821 & 13,9 & 13,0 & 139 \\
\hline 6 & 0,0959 & 78,2 & 76,4 & 64,6 & 0,0092 & 0,7 & 0,7 & 0,6 \\
\hline 7 & 0,3291 & 70,4 & 74,5 & 72,9 & 0,1083 & 7,6 & 8,1 & 79 \\
\hline 8 & 0,0196 & 75,3 & 75,2 & 68,7 & 0,0004 & 0,0 & 0,0 & 0,0 \\
\hline 9 & 0,3114 & 77,1 & 73,7 & 80,5 & 0,0970 & 7,5 & 7,1 & 7,8 \\
\hline 10 & 0,3218 & 71,5 & 77,6 & 77,8 & 0,1035 & 7,4 & 8,0 & 8,1 \\
\hline 11 & 0,6957 & 74,0 & 69,8 & 80,3 & 0,4841 & 35,8 & 33,8 & 38.8 \\
\hline 12 & 0,0478 & 72,8 & 78,4 & 69,8 & 0,0023 & 0,2 & 0,2 & 0,2 \\
\hline 13 & 0,3541 & 73,7 & 73,9 & 71,4 & 0,1254 & 9,2 & 93 & 9,0 \\
\hline 14 & 0,0403 & 73,1 & 73,9 & 72,5 & 0,0016 & 0,1 & 0,1 & 0,1 \\
\hline 15 & 0,4380 & 719 & 73,2 & 74,9 & 0,1919 & 13,8 & 14,1 & 14,4 \\
\hline 16 & 0,3097 & 74,3 & 73,2 & 70,3 & 0,0959 & 7,1 & 7,0 & 6,7 \\
\hline 17 & 0,4077 & 78,3 & 79,2 & 79,0 & 0,1662 & 13,0 & 13,2 & 13,1 \\
\hline 18 & 0,4539 & 71,8 & 74,3 & 77,9 & 0,2060 & 14,8 & 15,3 & 16,0 \\
\hline 19 & 0,0755 & 74,1 & 75,3 & 80,3 & 0,0057 & 0,4 & 0,4 & 0.5 \\
\hline 20 & 0,2961 & 74,7 & 72,4 & 72,1 & 0,0877 & 6,5 & 6,4 & 63 \\
\hline 21 & 0,4968 & 74,0 & 71,3 & 71,9 & 0,2468 & 18,3 & 17,6 & 17,7 \\
\hline 22 & 0,2742 & 70,6 & 78,5 & 76,6 & 0,0752 & 5,3 & 59 & 5,8 \\
\hline 23. & 0,6552 & 76,8 & 78,6 & 73,5 & 0,4293 & 33,0 & 33,8 & 31,6 \\
\hline 24 & 0,1904 & 75,3 & 71,2 & 77,6 & 0,0362 & 2,7 & 2,6 & 2,8 \\
\hline 25 & 0,4098 & 76,1 & 72,4 & 72,4 & 0,1679 & 12,8 & 12,2 & 12,2 \\
\hline 26 & 0,4388 & 70,7 & 78,9 & 69,0 & 0,1925 & 13,6 & 15,2 & 13,3 \\
\hline 27 & 0,4275 & 83,4 & 76,1 & 78,8 & 0,1828 & 15,2 & 139 & 14,4 \\
\hline 28 & 0,4226 & 70,8 & 76,6 & 79,0 & 0,1786 & 12,6 & 13,7 & 14,1 \\
\hline 29 & 0,4679 & 78,3 & 75,5 & 80,2 & 0.2189 & 17,1 & 16,5 & 17,6 \\
\hline 30 & 0,4428 & 76,7 & 76,4 & 73,8 & 0,1961 & 15,0 & 15,0 & 14,5 \\
\hline 31. & 0,1148 & 74,4 & 79,4 & 86,1 & 0,0132 & 1,0 & 1,0 & 1,1 \\
\hline 32 . & 0,4228 & 80,4 & 76,7 & 78,8 & 0,1787 & 14,4 & 13,7 & 14,1 \\
\hline 33 & 0,5417 & 66,5 & 71,0 & 71,4 & 0,2934 & 19,5 & 20,8 & 20,9 \\
\hline 34 & 0,2606 & 692 & 76,4 & 69,0 & 0,0679 & 4,7 & 5,2 & 4,7 \\
\hline 35 & 0,3095 & 82,7 & 86,1 & 80,0 & 0,0958 & 7,9 & 8,2 & 7,7 \\
\hline 36 & 0,3963 & 75,3 & 73,5 & 71,5 & 0,1570 & 11,8 & 115 & 112 \\
\hline 37. & 0,3651 & 82,5 & 79,3 & 70,8 & 0,1333 & 11,0 & 10,6 & 9,4 \\
\hline 38 & 0,0684 & 69,3 & 70,8 & 73,8 & 0,0047 & 0,3 & 0,3 & 0,3 \\
\hline 39 & 0,1005 & 77,5 & 80,6 & 77,9 & 0,0101 & 0,8 & 0,8 & 0,8 \\
\hline 40 & 0,6567 & 67,6 & 75,5 & 73,0 & 0,4312 & 29,1 & 32,6 & 31,5 \\
\hline 41 . & 0,0994 & 80,3 & 75,7 & 74,8 & 0,0099 & 0,8 & 0,7 & 0,7 \\
\hline 42 & 0,3149 & 70,3 & 74,2 & 68,5 & 0,0992 & 7,0 & 7,4 & 6,8 \\
\hline \multicolumn{5}{|c|}{$\Sigma$} & 6,0264 & 445,8 & 452,1 & 450,5 \\
\hline \multicolumn{6}{|c|}{$V_{k j}=\frac{\sum_{i=1}^{42}\left(\left(\mu_{i k}\right)^{2} * X_{i j}\right)}{\sum_{i=1}^{42}\left(\mu_{i k}\right)^{2}}$} & 74,0 & 75,0 & 74,7 \\
\hline
\end{tabular}

Gambar 6. Hasil Perhitungan inti cluster pada Iterasi Pertama Klaster ke-1

Hasil perhitungan pusat Klaster pada iterasi pertama klaster ke-3 dapat dilihat pada Gambar 7. 


\begin{tabular}{|c|c|c|c|c|c|c|c|c|}
\hline \multirow{2}{*}{ Sgra } & \multirow{2}{*}{\begin{tabular}{|l|}
$\begin{array}{l}\text { Derajat } \\
\text { Keanggotasn } \\
\text { Pada Klaster ke-3 }\end{array}$ \\
(ui3) \\
\end{tabular}} & \multicolumn{3}{|c|}{ Data yang diklaster } & \multirow{2}{*}{$(\mu i 3)^{2}$} & \multirow{2}{*}{$(\mu \mathrm{i3})^{2} \times \mathrm{X} \mid 1$} & \multirow{2}{*}{$(\mu \mathrm{i} 3)^{2} \times \times 12$} & \multirow{2}{*}{$\left.(\mu \mathrm{i})^{2}\right)^{2} \times 13$} \\
\hline & & $\mathrm{x} 11$ & $\mathrm{x} 12$ & $\mathrm{x} 13$ & & & & \\
\hline 1 & 0,0687 & 72,2 & 74,8 & 76,5 & 0,0047 & 0,3 & 0,4 & 0,4 \\
\hline 2 & 0,0594 & 749 & 76,5 & 67,3 & 0,0035 & 0,3 & 0.3 & 0,2 \\
\hline 3 & 0,5371 & 77,5 & 70,6 & 74,6 & 0,2884 & 22,4 & 20,4 & 21,5 \\
\hline 4 & 0,4637 & 68,1 & 77,1 & 77,8 & 0,2150 & 14,6 & 16,6 & 16,7 \\
\hline 5 & 0,3568 & 76,6 & 71,3 & 76,1 & 0,1273 & 9,7 & 9,1 & 9,7 \\
\hline 6 & 0,6190 & 78,2 & 76,4 & 64,6 & 0,3832 & 30,0 & 29,3 & 24,7 \\
\hline 7 & 0,2724 & 70,4 & 74,5 & 72,9 & 0,0742 & 5,2 & 5.5 & 5,4 \\
\hline 8 & 0,5135 & 753 & 75,2 & 68,7 & 0,2637 & 19,9 & 19,8 & 18,1 \\
\hline 9 & 0,3409 & 77,1 & 73,7 & 80,5 & 0,1162 & 9,0 & 8,6 & 9,4 \\
\hline 10 & 0,1404 & 71,5 & 77,6 & 77,8 & 0,0197 & 1,4 & 1,5 & 1,5 \\
\hline 11 & 0,2729 & 74,0 & 69,8 & 80,3 & 0,0745 & 5,5 & 5,2 & 6,0 \\
\hline 12 & 0,8518 & 72,8 & 78,4 & 69,8 & 0,7255 & 52,8 & 569 & 50,6 \\
\hline 13 & 0,4843 & 73,7 & 73,9 & 71,4 & 0,2345 & 17,3 & 173 & 167 \\
\hline 14 & 0,4464 & 73,1 & 73,9 & 72,5 & 0,1993 & 14,6 & 14,7 & 14,5 \\
\hline 15 & 0,1069 & 719 & 73,2 & 74,9 & 0,0114 & 0,8 & 0,8 & 0,9 \\
\hline 16 & 0,4086 & 74,3 & 73,2 & 70,3 & 0,1670 & 12,4 & 12,2 & 11,7 \\
\hline 17 & 0,1586 & 783 & 79,2 & 79,0 & 0,0252 & 2,0 & 2,0 & 2,0 \\
\hline 18 & 0,1086 & 71,8 & 74,3 & 77,9 & 0,0118 & 0,8 & 0,9 & 0,9 \\
\hline 19 & 0,6085 & 74,1 & 75,3 & 80,3 & 0,3703 & 27,4 & 279 & 29,7 \\
\hline 20 & 0,1947 & 74,7 & 72,4 & 72,1 & 0,0379 & 2,8 & 2,7 & 2,7 \\
\hline 21 & 0,3346 & 74,0 & 71,3 & 71,9 & 0,1119 & 8,3 & 8,0 & 8,0 \\
\hline 22 & 0,3763 & 70,6 & 78,5 & 76,6 & 0,1416 & 10,0 & 11,1 & 10,9 \\
\hline 23 & 0,1788 & 76,8 & 78,6 & 73,5 & 0,0320 & 2,5 & 2,5 & 23 \\
\hline 24 & 0,1880 & 75,3 & 71,2 & 77,6 & 0,0353 & 2,7 & 2,5 & 2,7 \\
\hline 25 & 0,4677 & 76,1 & 72,4 & 72,4 & 0,2187 & 16,6 & 15,8 & 15,8 \\
\hline 26 & 0,3148 & 70,7 & 78,9 & 69,0 & 0,0991 & 7,0 & 7,8 & 6,8 \\
\hline 27 & 0,2440 & 83,4 & 76,1 & 78,8 & 0,0596 & 5,0 & 4,5 & 4,7 \\
\hline 28 & 0,2796 & 70,8 & 76,6 & 79,0 & 0,0782 & 5,5 & 6,0 & 62 \\
\hline 29 & 0,3863 & 783 & 75,5 & 80,2 & 0,1492 & 11,7 & 113 & 12,0 \\
\hline 30 & 0,3336 & 76,7 & 76,4 & 73,8 & 0,1113 & 8,5 & 8,5 & 8,2 \\
\hline 31 & 0,8035 & 74,4 & 79,4 & 86,1 & 0,6456 & 48,1 & 51,2 & 55,6 \\
\hline 32 & 0,0705 & 80,4 & 76,7 & 78,8 & 0,0050 & 0,4 & 0,4 & 0,4 \\
\hline 33 & 0,0113 & 665 & 71,0 & 71,4 & 0,0001 & 0,0 & 0,0 & 0,0 \\
\hline 34 & 0,6140 & 69,2 & 76,4 & 69,0 & 0,3770 & 26,1 & 28,8 & 26,0 \\
\hline 35 & 0,1648 & 82,7 & 86,1 & 80,0 & 0,0271 & 2,2 & 23 & 2,2 \\
\hline 36 & 0,4306 & 75,3 & 73,5 & 71,5 & 0,1854 & 14,0 & 13,6 & 133 \\
\hline 37 & 0,2386 & 82,5 & 79,3 & 70,8 & 0,0570 & 4,7 & 4,5 & 4,0 \\
\hline 38 & 0,7449 & 693 & 70,8 & 73,8 & 0,5549 & 38,5 & 39,3 & 409 \\
\hline 39 & 0,3550 & 77,5 & 80,6 & 77,9 & 0,1260 & 9,8 & 10,2 & 9,8 \\
\hline 40 & 0,2918 & 67,6 & 75,5 & 73,0 & 0,0852 & 5,8 & 6,4 & 6,2 \\
\hline 41 & 0,0043 & 80,3 & 75,7 & 74,8 & 0,0000 & 0,0 & 0,0 & 0,0 \\
\hline 42 & 0,3530 & 70,3 & 74,2 & 68,5 & 0,1246 & 8,8 & 9,2 & 8,5 \\
\hline \multicolumn{5}{|c|}{$\Sigma$} & 6,5782 & 485,2 & 496,1 & 488,0 \\
\hline \multicolumn{6}{|c|}{$V_{k j}=\frac{\sum_{i=1}^{42}\left(\left(\mu_{i k}\right)^{2} \cdot X_{i j}\right)}{\sum_{i=1}^{42}\left(\mu_{i k}\right)^{2}}$} & 73,8 & 75,4 & 74,2 \\
\hline
\end{tabular}

Gambar 7. Hasil Perhitungan Pusat Klaster pada Iterasi Pertama Klaster ke-3

Pusat Klaster $\mathrm{V}$ yang terbentuk pada iterasi pertama:

$$
\mathrm{V}_{1}=\left(\begin{array}{ccc}
4,0 & 75,0 & 74,7 \\
75,7 & 75,7 & 75,0 \\
73,8 & 75,4 & 74,2
\end{array}\right]
$$

\section{Menghitung Fungsi Objektif $P$}

Fungsi objektif pada iterasi pertama (p1) dihitung dengan menggunakan persamaan :

$$
P_{1=\sum_{i=1}^{42} \sum_{k=1}^{3}\left(\left[\sum_{j=1}^{3}\left(X_{i j}-V_{k j}\right)^{2}\right]\left(\mu_{i k}\right)^{2}\right)=863,8398}
$$

Hasil perhitungan secara rinci dapat dilihat pada

\begin{tabular}{|c|c|c|c|c|c|c|c|}
\hline \multirow[t]{2}{*}{ Эжа } & \multicolumn{3}{|c|}{$\begin{array}{c}\text { Kuadrat Derajat Keanggotasn } \\
\text { Data ke i }\end{array}$} & \multirow[t]{2}{*}{ L1 } & \multirow[t]{2}{*}{$\mathrm{L} 2$} & \multirow[t]{2}{*}{ L3 } & \multirow{2}{*}{$\begin{array}{c}L T= \\
L 1+L 2+L 3\end{array}$} \\
\hline & $\mu_{i 1}{ }^{2}$ & $\mu_{i 2^{2}}{ }^{2}$ & $\mu_{i} 3^{2}$ & & & & \\
\hline 1 & 0,1945 & 0,2404 & 0,0047 & 1,2681 & 3,6805 & 0,0386 & 4,9873 \\
\hline 2 & 0,3089 & 0,1481 & 0,0035 & 17,8606 & 8,9704 & 0,1751 & 27,0061 \\
\hline 3 & 0,0244 & 0,0941 & 0,2884 & 0,7715 & 2,7675 & 10,6391 & 14,1781 \\
\hline 4 & 0,2125 & 0,0057 & 0,215 & 10,3764 & 0,3851 & 10,3931 & 21,1546 \\
\hline 5 & 0,1821 & 0,0468 & 0,1273 & 4,0809 & 1,0006 & 3,5975 & 8,6789 \\
\hline 6 & 0,0092 & 0,0813 & 0,3832 & 1,1188 & 9,3414 & 43,1177 & 53,5778 \\
\hline 7 & 0,1083 & 0,1588 & 0,0742 & 1,7815 & 5,3897 & 1,0433 & 8,2145 \\
\hline 8 & 0,0004 & 0,218 & 0,2637 & 0,0151 & 8,7418 & 8,5808 & 17,3377 \\
\hline 9 & 0,097 & 0,1209 & 0,1162 & 4,3592 & 4,3778 & 6,2132 & 14,9502 \\
\hline 10 & 0,1035 & 0,2892 & 0,0197 & 2,3412 & 8,4128 & 0,4549 & 11,2089 \\
\hline 11 & 0,4841 & 0,001 & 0,0745 & 28,2714 & 0,0658 & 5,1114 & 33,4487 \\
\hline 12 & 0,0023 & 0,0101 & 0,7255 & 0,0851 & 0,4317 & 21,3007 & 21,8175 \\
\hline 13 & 0,1254 & 0,0261 & 0,2345 & 1,5286 & 0,5272 & 2,3685 & 4,4243 \\
\hline 14 & 0,0016 & 0,2635 & 0,1993 & 0,0110 & 4,2819 & 1,1221 & 5,4149 \\
\hline 15 & 0,1919 & 0,207 & 0,0114 & 1,4757 & $\begin{array}{r}4,2849 \\
-\end{array}$ & 0,1019 & 5,8625 \\
\hline 16 & 0,0959 & 0,0794 & 0,167 & 2,1760 & 2,4058 & 3,3901 & 7,9719 \\
\hline 17 & 0,1662 & 0,1881 & 0,0252 & 9,0778 & 6,5854 & 1,4548 & 17,1180 \\
\hline 18 & 0,206 & 0,1914 & 0,0118 & 3,2074 & 4,8960 & 0,2230 & 8,3265 \\
\hline 19 & 0,0057 & 0,0999 & 0,3703 & 0,1793 & 3,0779 & 13,8159 & 17,0731 \\
\hline 20 & 0,0877 & 0,2592 & 0,0379 & 1,2287 & 5,2618 & 0,5389 & 7,0294 \\
\hline 21 & 0,2468 & 0,0285 & $\begin{array}{l}0,1119 \\
0\end{array}$ & 5,3136 & 0,9080 & 2,4775 & 8,6991 \\
\hline 22 & 0,0752 & 0,1221 & 0,1416 & 2,0620 & 4,4457 & 3,6264 & 10,1340 \\
\hline 23 & 0,4293 & 0,0276 & 0,032 & 9,5476 & 0,3276 & 0,6314 & 10,5066 \\
\hline 24 & 0,0362 & 0,3864 & 0,0353 & 0,8883 & 10,4985 & 1,1102 & 12,4970 \\
\hline 25 & 0,1679 & 0,015 & 0,2187 & 2,7636 & 0,2671 & 3,8338 & 6,8646 \\
\hline 26 & 0,1925 & 0,0607 & 0,0991 & 11,2786 & 4,3243 & 4,8460 & 20,4488 \\
\hline 27 & 0,1828 & 0,1079 & 0,0596 & 19,4463 & 7,9727 & 6,7831 & 34,2021 \\
\hline 28 & 0,1786 & 0,0886 & 0,0782 & 5,5884 & 3,6167 & 2,6181 & 11,8232 \\
\hline 29 & 0,2189 & 0,0213 & 0,1492 & 10,7239 & 0,7208 & 8,3940 & 19,8387 \\
\hline 30 & 0,1961 & 0,05 & 0,1113 & 1,9728 & 0,1465 & 1,0651 & 3,1844 \\
\hline 31 & 0,0132 & 0,0067 & 0,6456 & 1,9731 & 0,9286 & 101,9854 & 104,8871 \\
\hline 32 & 0,1787 & 0,2568 & 0,005 & 10,8399 & 9,6377 & 0,3321 & 20,8097 \\
\hline 33 & 0,2934 & 0,1998 & 0,0001 & 24,3933 & 23,9141 & 0,0080 & 48,3154 \\
\hline 34 & 0,0679 & 0,0157 & 0,377 & 3,9036 & 1,2362 & 18,5484 & 23,6882 \\
\hline 35 & 0,0958 & 0,2764 & 0,0271 & 21,7456 & 50,3490 & 6,1609 & 78,2556 \\
\hline 36 & 0,157 & 0,03 & 0,1854 & 2,2263 & 0,5175 & 2,4380 & 5,1818 \\
\hline 37 & 0,1333 & 0,157 & 0,057 & 14,1231 & 12,0639 & 5,8402 & 32,0272 \\
\hline 38 & 0,0047 & 0,0349 & 0,5549 & 0,1905 & 2,3177 & 23,0672 & 25,5754 \\
\hline 39 & 0,0101 & 0,2965 & 0,126 & 0,5439 & 10,5732 & 6,8569 & 17,9740 \\
\hline 40 & 0,4312 & 0,0027 & 0,0852 & 19,0159 & 0,1881 & 3,3986 & 22,6026 \\
\hline 41 & 0,0099 & 0,8034 & 0,0001 & 0,3979 & 17,0321 & 0,0001 & 17,4300 \\
\hline 42 & 0,0992 & 0,1103 & 0,1246 & 5,2348 & 8,1247 & 5,7540 & 19,1135 \\
\hline & & & & & ungsi $O$ bje & ive $=\Sigma$ & 863,8398 \\
\hline
\end{tabular}
Gambar 8.

Gambar 8. Hasil Perhitungan Fungsi Objektif pada Iterasi Pertama

Perhitungan L1, L2 dan L3 adalah :

$$
\begin{aligned}
& L 1=\left[\sum_{j=1}^{3}\left(X_{i j}-V_{1 j}\right)^{2}\right]\left(\mu_{i 1}\right)^{2} \\
& L 2=\left[\sum_{j=1}^{3}\left(X_{i j}-V_{2 j}\right)^{2}\right]\left(\mu_{i 2}\right)^{2}
\end{aligned}
$$




$$
L 3=\left[\sum_{j=1}^{3}\left(X_{i j}-V_{3 j}\right)^{2}\right]\left(\mu_{i 3}\right)^{2}
$$

\section{Menghitung Perubahan Matriks Partisi U}

Perubahan matriks partisi (U) dihitung menggunakan persamaan:

$$
\mu_{i k}=\frac{\left[\sum_{j=1}^{3}\left(X_{i j}-V_{k j}\right)^{2}\right]^{\frac{-1}{2-1}}}{\sum_{k=1}^{c}\left[\sum_{j=1}^{3}\left(X_{i j}-V_{k j}\right)^{2}\right]^{\frac{-1}{2-1}}}
$$

Hasil perhitungan secara rinci dapat dilihat

\begin{tabular}{|c|c|c|c|c|c|c|c|}
\hline \multirow[t]{2}{*}{ Эঞма } & \multirow[t]{2}{*}{ L1 } & \multirow[t]{2}{*}{ L2 } & \multirow{2}{*}{ L3 } & \multirow[t]{2}{*}{ LT } & $\mu_{i} 1$ & $\mathrm{Hi}_{2}$ & $\mu_{i 3}$ \\
\hline & & & & & L1/LT & L'LT & L3/LT \\
\hline 1 & 1,2681 & 3,6805 & 0,0386 & 4,9873 & 0,2543 & 0,7380 & 0,0077 \\
\hline 2 & 17,8606 & 8,9704 & 0,1751 & 27,0061 & 0,6614 & 0,3322 & 0,0065 \\
\hline 3 & 0,7715 & 2,7675 & 10,6391 & 14,1781 & 0,0544 & 0,1952 & 0,7504 \\
\hline 4 & 10,3764 & 0,3851 & 10,3931 & 21,1546 & 0,4905 & 0,0182 & 0,4913 \\
\hline 5 & 4,0809 & 1,0006 & 3,5975 & 8,6789 & 0,4702 & 0,1153 & 0,4145 \\
\hline 6 & 1,1188 & 9,3414 & 43,1177 & 53,5778 & 0,0209 & 0,1744 & 0,8048 \\
\hline 7 & 1,7815 & 5,3897 & 1,0433 & 8,2145 & 0,2169 & 0,6561 & 0,1270 \\
\hline 8 & 0,0151 & 8,7418 & 8,5808 & 17,3377 & 0,0009 & 0,5042 & 0,4949 \\
\hline 9 & 4,3592 & 4,3778 & 6,2132 & 14,9502 & 0,2916 & 0,2928 & 0,4156 \\
\hline 10 & 2,3412 & 8,4128 & $\begin{array}{l}0,4549 \\
.\end{array}$ & 11,2089 & 0,2089 & 0,7506 & 0,0406 \\
\hline 11 & 28,2714 & 0,0658 & 5,1114 & 33,4487 & 0,8452 & 0,0020 & $\begin{array}{l}0,1528 \\
0\end{array}$ \\
\hline 12 & 0,0851 & 0,4317 & 21,3007 & 21,8175 & 0,0039 & 0,0198 & $\begin{array}{l}0,9763 \\
0 .\end{array}$ \\
\hline 13 & 1,5286 & 0,5272 & 2,3685 & 4,4243 & 0,3455 & 0,1192 & 0,5353 \\
\hline 14 & 0,0110 & 4,2819 & 1,1221 & 5,4149 & 0,0020 & 0,7908 & 0,2072 \\
\hline 15 & 1,4757 & 4,2849 & 0,1019 & 5,8625 & 0,2517 & 0,7309 & 0,0174 \\
\hline .16 & 2,1760 & 2,4058 & 3,3901 & 7,9719 & 0,2730 & 0,3018 & 0,4253 \\
\hline 17. & 9,0778 & 6,5854 & 1,4548 & 17,1180 & 0,5303 & 0,3847 & 0,0850 \\
\hline 18 & 3,2074 & 4,8960 & 0,2230 & 8,3265 & 0,3852 & 0,5880 & 0,0268 \\
\hline 19 & 0,1793 & 3,0779 & 13,8159 & 17,0731 & 0,0105 & 0,1803 & 0,8092 \\
\hline 20 & 1,2287 & 5,2618 & 0,5389 & 7,0294 & 0,1748 & 0,7485 & 0,0767 \\
\hline 21 & 5,3136 & 0,9080 & 2,4775 & 8,6991 & 0,6108 & 0,1044 & 0,2848 \\
\hline 22 & 2,0620 & 4,4457 & $\begin{array}{l}3,6264 \\
.6\end{array}$ & 10,1340 & 0,2035 & $\begin{array}{l}0,4387 \\
.0,\end{array}$ & $\begin{array}{l}0,3578 \\
0.2\end{array}$ \\
\hline 23 & 9,5476 & 0,3276 & 0,6314 & 10,5066 & 0,9087 & 0,0312 & 0,0601 \\
\hline 24 & 0,8883 & 10,4985 & 1,1102 & 12,4970 & 0,0711 & 0,8401 & 0,0888 \\
\hline 25 & 2,7636 & 0,2671 & $\begin{array}{l}3,8338 \\
3 \ldots\end{array}$ & 6,8646 & 0,4026 & 0,0389 & 0,5585 \\
\hline 26 & 11,2786 & 4,3243 & 4,8460 & 20,4488 & 0,5516 & 0,2115 & 0,2370 \\
\hline 27 & 19,4463 & 7,9727 & 6,7831 & 34,2021 & 0,5686 & 0,2331 & 0,1983 \\
\hline 28 & 5,5884 & 3,6167 & 2,6181 & 11,8232 & 0,4727 & 0,3059 & 0,2214 \\
\hline 29 & 10,7239 & 0,7208 & 8,3940 & 19,8387 & 0,5406 & 0,0363 & 0,4231 \\
\hline 30 & 1,9728 & 0,1465 & 1,0651 & 3,1844 & 0,6195 & 0,0460 & 0,3345 \\
\hline 31 & 1,9731 & 0,9286 & 101,9854 & 104,8871 & 0,0188 & 0,0089 & 0,9723 \\
\hline 32 & 10,8399 & 9,6377 & 0,3321 & 20,8097 & 0,5209 & $\begin{array}{l}0,4631 \\
0.2\end{array}$ & 0,0160 \\
\hline 33 & 24,3933 & 23,9141 & 0,0080 & 48,3154 & 0,5049 & 0,4950 & 0,0002 \\
\hline 34 & 3,9036 & 1,2362 & 18,5484 & 23,6882 & 0,1648 & 0,0522 & 0,7830 \\
\hline 35 & 21,7456 & 50,3490 & 6,1609 & 78,2556 & 0,2779 & 0,6434 & 0,0787 \\
\hline 36 & 2,2263 & 0,5175 & 2,4380 & 5,1818 & 0,4296 & 0,0999 & 0,4705 \\
\hline 37 & 14,1231 & 12,0639 & 5,8402 & 32,0272 & 0,4410 & 0,3767 & 0,1824 \\
\hline 38 & 0,1905 & 2,3177 & 23,0672 & 25,5754 & 0,0075 & 0,0906 & 0,9019 \\
\hline 39 & 0,5439 & 10,5732 & 6,8569 & 17,9740 & 0,0303 & 0,5882 & 0,3815 \\
\hline 40 & 19,0159 & 0,1881 & 3,3986 & 22,6026 & 0,8413 & 0,0083 & 0,1504 \\
\hline 41 & 0,3979 & 17,0321 & 0,0001 & 17,4300 & 0,0228 & 0,9772 & 0,0001 \\
\hline 42 & 5,2348 & 8,1247 & 5,7540 & 19,1135 & 0,2739 & 0,4251 & 0,3010 \\
\hline
\end{tabular}
pada Gambar 9.

Gambar 9. Hasil Perhitungan Derajat Keanggotaan Baru (Matriks Partisi Baru)
Hasil matrik partisi baru (U) untuk iterasi kedua dapat dilihat pada Gambar 10.

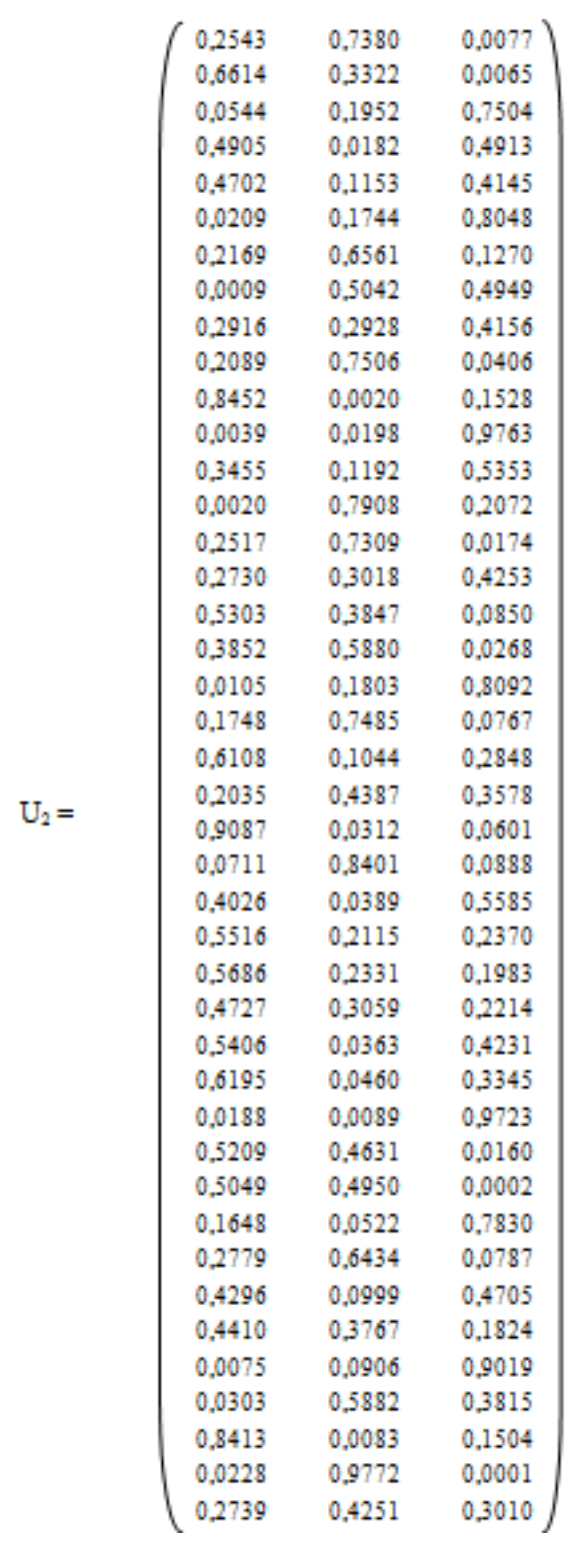

Gambar 10. Matriks partisi baru (U)

7. Mengecek Kondisi Berhenti

Karena $\left|P_{1}-P_{0}\right|=|863,8398-0|=863,8398$ $>>\left(10^{-5}\right)$, dan interasi $=1<$ MaxIter $(=100)$, maka proses dilanjutkan ke iterasi kedua $(\mathrm{t}=2)$.

Pada iterasi kedua ditentukan kembali 3 pusat klaster $\mathrm{V}_{\mathrm{kj}}$ (seperti langkah perhitungan pada 
iterasi pertama) dengan nilai $\mathrm{k}=1,2,3$ dan $\mathrm{j}=$ 1,2,3. Hasilnya seperti berikut:

$$
\mathrm{V}_{2}=\left(\begin{array}{lll}
74,5 & 75,3 & 74,7 \\
74,8 & 75,4 & 75,1 \\
73,9 & 75,3 & 74,3
\end{array}\right]
$$

Fungsi obyektif pada iterasi kedua (P2) dihitung seperti cara perhitungan fungsi obyektif pada iterasi pertama. Dimana hasil perhitungan adalah:

$$
P_{2=\sum_{i=1}^{42} \sum_{k=1}^{3}\left(\left[\sum_{j=1}^{3}\left(X_{i j}-V_{k j}\right)^{2}\right]\left(\mu_{i k}\right)^{2}\right)=1.102,4291}
$$

Hasil perbaikan matriks partisi $\mathrm{U}$ dapat dilihat pada Gambar 11.

$$
\left.\begin{array}{llll}
0,1030 & 0,8968 & 0,0001 \\
0,7825 & 0,2175 & 0,0001 \\
0,0044 & 0,0554 & 0,9402 \\
0,5216 & 0,0007 & 0,4778 \\
0,5055 & 0,0286 & 0,4659 \\
0,0006 & 0,0482 & 0,9512 \\
0,0812 & 0,8989 & 0,0200 \\
0,0000 & 0,5623 & 0,4377 \\
0,2326 & 0,2038 & 0,5636 \\
0,0742 & 0,9232 & 0,0027 \\
0,9662 & 0,0001 & 0,0338 \\
0,0001 & 0,0006 & 0,9994 \\
0,3330 & 0,0504 & 0,6166 \\
0,0001 & 0,9674 & 0,0326 \\
0,0910 & 0,9087 & 0,0003 \\
0,2201 & 0,3180 & 0,4618 \\
0,6719 & 0,3078 & 0,0202 \\
0,3055 & 0,6931 & 0,0014 \\
0,0001 & 0,0365 & 0,9633 \\
0,0437 & 0,9485 & 0,0077 \\
0,8130 & 0,0273 & 0,1597 \\
0,1172 & 0,5533 & 0,3295 \\
0,9939 & 0,0011 & 0,0049 \\
0,0076 & 0,9790 & 0,0135 \\
0,3327 & 0,0034 & 0,6639 \\
0,7572 & 0,1231 & 0,1198 \\
0,7734 & 0,1185 & 0,1081 \\
0,6172 & 0,2493 & 0,1335 \\
0,5727 & 0,0022 & 0,4252 \\
0,7141 & 0,0036 & 0,2823 \\
0,0004 & 0,0001 & 0,9995 \\
0,5914 & 0,4079 & 0,0008 \\
0,4880 & 0,5120 & 0,0001 \\
0,0504 & 0,0056 & 0,9440 \\
0,1621 & 0,8240 & 0,0139 \\
0,4604 & 0,0297 & 0,5099 \\
0,5273 & 0,3757 & 0,0969 \\
0,0127 & 0,9872 \\
0,5774 & 0,3494 \\
0,0002 & 0,2121
\end{array}\right)
$$

Gambar 11. Matriks perbaikan partisi baru (U)
Karena $\left|P_{2}-P_{1}\right|=|1.102,4291-863,8398|=$ $238,5893 \gg \varepsilon_{0}\left(10^{-5}\right)$, dan interasi $=2<$ MaxIter $(=100)$, maka proses dilanjutkan ke iterasi ketiga $(\mathrm{t}=3)$.

Proses ini dilakukan terus menerus hingga diperoleh $\left|P_{t}-P_{t-1}\right|<\xi$, atau $\mathrm{t}>$ MaxIter. Dalam penelitian ini, proses iterasi berhenti setelah iterasi ke-33.

> $[$ center,U,ObjFcn $]=\mathrm{fcm}\left(\mathrm{X}, 3,\left[2,100,10^{\wedge}-5\right]\right)$

Iteration count $=1$, obj. $\mathrm{fcn}=896.896246$

Iteration count $=2$, obj. $\mathrm{fcn}=642.795320$

Iteration count $=3$, obj. $\mathrm{fcn}=637.785642$

Iteration count $=4$, obj. $\mathrm{fcn}=629.744333$

Iteration count $=5$, obj. $\mathrm{fcn}=616.896816$

Iteration count $=6, \mathrm{obj} . \mathrm{fcn}=599.368576$

Iteration count $=7, \mathrm{obj} . \mathrm{fcn}=582.013431$

Iteration count $=8, \mathrm{obj} . \mathrm{fcn}=570.019693$

Iteration count $=9$, obj. $\mathrm{fcn}=563.887165$

Iteration count $=10$, obj. $\mathrm{fcn}=561.104961$

Iteration count $=11$, obj. $\mathrm{fcn}=559.707264$

Iteration count $=12$, obj. $\mathrm{fcn}=558.909844$

Iteration count $=13$, obj. $\mathrm{fcn}=558.431176$

Iteration count $=14$, obj. $\mathrm{fcn}=558.142447$

Iteration count $=15$, obj. $\mathrm{fcn}=557.969914$

Iteration count $=16$, obj. $\mathrm{fcn}=557.867965$

Iteration count $=17$, obj. $\mathrm{fcn}=557.808301$

Iteration count $=18$, obj. fcn $=557.773644$

Iteration count $=19$, obj. $\mathrm{fcn}=557.753627$

Iteration count $=20$, obj. $\mathrm{fcn}=557.742115$

Iteration count $=21$, obj. $\mathrm{fcn}=557.735515$

Iteration count $=22$, obj. $\mathrm{fcn}=557.731740$

Iteration count $=23$, obj. $\mathrm{fcn}=557.729585$

Iteration count $=24$, obj. fen $=557.728356$

Iteration count $=25$, obj. fcn $=557.727657$

Iteration count $=26$, obj. $\mathrm{fcn}=557.727258$

Iteration count $=27$, obj. $\mathrm{fcn}=557.727032$

Iteration count $=28$, obj. $\mathrm{fcn}=557.726903$

Iteration count $=29$, obj. $\mathrm{fcn}=557.726829$

Iteration count $=30$, obj. fcn $=557.726788$

Iteration count $=31$, obj. $\mathrm{fcn}=557.726764$

Iteration count $=32$, obj. $\mathrm{fcn}=557.726751$

Iteration count $=33$, obj. $\mathrm{fcn}=557.726743$ 


$$
\text { Center }=\begin{array}{rrr}
73.8086 & 75.1587 & 76.6170 \\
71.9354 & 74.3454 & 70.9887 \\
78.8520 & 77.3860 & 78.1443
\end{array}
$$

Pada iterasi terakhir (iterasi ke-33) ini, pusat kelaster $\mathrm{V}_{\mathrm{kj}}$ yang dihasilkan (Software Matlab) dengan $\mathrm{k}=1,2,3$; dan $\mathrm{j}=1,2,3$ adalah:

$$
V=\left[\begin{array}{lll}
73,8086 & 75,1587 & 76,6170 \\
71,9354 & 74,3454 & 70,9887 \\
78,8520 & 77,3860 & 78,1443
\end{array}\right]
$$

dapat disimpulkan:

1. Kelompok/klaster pertama berisi siswa nomor $1,4,5,10,11,15$ dan 18, 19, 22, 24, 28, 38 dan 40.

2. Kelompok/klaster kedua berisi siswa nomor 2, 3, 6, 7, 8, 11, 12, 13, 14, 16, 20, $21,25,26,30,33,34,36$ dan 42

3. Kelompok/klaster ketiga berisi siswa nomor 9 dan 17, 23, 27, 29, 31, 32, 35, 37, 39 dan 41

\section{Pembahasan}

Penetapan hasil akurasi didasarkan pada ketentuan bahwa jika nilai peminatan yang dipilih lebih besar dari standar Kriteria Ideal Ketuntasan (KKM) yaitu lebih besar atau sama dengan 75 maka peminatan yang dilakukan oleh algoritma FCM dianggap TIDAK AKURAT, sedangkan jika nilai peminatan yang dipilih lebih kecil dari KKM maka peminatan yang dilakukan oleh algoritma FCM dianggap AKURAT. Akurasi

\begin{tabular}{|c|c|c|c|c|c|c|}
\hline \multirow[t]{2}{*}{ צs: } & \multicolumn{2}{|c|}{ Huil XI watering Peninatum } & \multicolumn{2}{|c|}{ 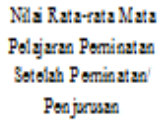 } & \multicolumn{2}{|c|}{ Hasil } \\
\hline & Yan $801 p \mid 111 n$ & CAMsas & Kelas XI & Kolas XII & Kelas X & Kolas XII \\
\hline 1 & Bahasa & Bahasa & 75.5 & 742 & Alwurat & Tidds: Alurat \\
\hline 2 & $\mathbb{P S S}$ & IPS & 77.0 & 75.5 & Akurst & Akurat \\
\hline 3 & $\mathrm{IPA}$ & IPS & 75,5 & 78.0 & Tidsk Akurat & Tidak Akurat \\
\hline 4 & Bahasa & Bahasa & 77,0 & 75.5 & Akurat & Akurst \\
\hline 5 & IPA & Bahasa & 72.8 & 71.5 & Akurst & Akurst \\
\hline 6 & $\mathrm{IPA}$ & IPS & 71,5 & 74,5 & Akurst & Akurst \\
\hline 7 & IPS & IPS & 69,0 & 645 & Tidak Akurst & Tidak Akurst \\
\hline 8 & $\mathrm{IPA}$ & IPS & 70.5 & 2.5 & Akurst & Akurst \\
\hline 9 & $\begin{array}{l}\text { Bahasa } \\
\end{array}$ & $\mathrm{IPA}$ & .74 .3 & 2.5 & Akurst & Akurst \\
\hline 10 & Bahasa & Bahasa & 78,0 & 76,5 & Akurst & Akurst \\
\hline 11 & Bahasa & Bahasa & 75,5 & 79,0 & Akurst & Akurst \\
\hline 12 & IPS & IPS & 85.2 & 80.5 & Akurst & Akurst \\
\hline 13 & IPS & IPS & 81.5 & 85.0 & Akurst & Akurst \\
\hline 14 & IPS & IPS & 77,5 & 75,3 & Akurst & Akurst \\
\hline 15 & Bahasa & Bahasa & 75.5 & 69.5 & Akurst & Tid sk Aku rat \\
\hline 16 & $\mathrm{IPA}$ & IPS & 74,3 & 713 & Akurst & Akurst \\
\hline 17 & $\mathrm{IPS}$ & $\mathrm{IPA}$ & 80,7 & 82.5 & Tidsk Aku rat: & Tid sk Aku rat \\
\hline 18 & Bahasa & Bahasa & 76,0 & 80,5 & Akurst & Akurst \\
\hline 19 & Bahasa & Bahasa & 78.5 & 82.5 & Akurst & Akurst \\
\hline 20 & $\mathrm{IPA}$ & IPS & 74,0 & 71.0 & Akurst & Akurst \\
\hline 21 & IPA & IPS & 69.5 & 735 & Akurst & Akurst \\
\hline 22 & IPS & Bahasa & 82,5 & 79,5 & Tid ak Aku rst & Tid sk Aku rst \\
\hline 23 & IPS & $\mathrm{IPA}$ & 72.5 & 20.8 & Aku rat & Aku ret \\
\hline 24 & Bahasa & $\mathrm{IPA}$ & 65.5 & 70,5 & Akurat & Akurat \\
\hline 25 & $\mathrm{IPA}$ & $I \mathbb{P S}$ & .76 .0 & 783 & Tidgk Aku rat & Tid sk Aku rst \\
\hline 26 & IPS & IPS & 78,0 & 76,5 & Aku rst & Akurst \\
\hline 27 & $\mathrm{IPA}$ & $\mathbb{P A}$ & 77,5 & 81.0 & Akurat & Akurst \\
\hline 28 & $\begin{array}{l}\text { Bahasa } \\
\text {. }\end{array}$ & $\begin{array}{l}\text { Bahasa } \\
a n\end{array}$ & 81,0 & $.76,5$ & Akurst & Akurst \\
\hline 29 & Bahasa & IPS & 720 & 70,0 & Akurst: & Akurst \\
\hline 30 & $\mathrm{IPA}$ & $\mathbb{I P S}$ & 72.5 & 67.8 & Akurst & Akurat \\
\hline 31 & Bahasa & $\mathrm{PA}$ & 719 & 73.5 & Akurst: & Akurst \\
\hline 32 & $\mathrm{IPA}$ & $\mathrm{PA}$ & $.70,7$ & 2.5 & Tidgk Aku rat & Tidsk Aku rst \\
\hline 33 & Bahasa & IPS & 70,5 & 68,5 & Akurst & Akurst \\
\hline 34 & IPS & IPS & 82,75 & .80 .5 & Akurst & Akurst \\
\hline 35 & IPS & $\mathrm{IPA}$ & 735 & 77.5 & Akurat & Akurat \\
\hline 36 & $\mathrm{IPA}$ & IPS & 782 & 75,5 & Tidgk Akurst & Tidsk Akurst \\
\hline 37 & $\mathrm{IPA}$ & $\mathbb{P A}$ & 78.5 & 82,0 & Akurat & Akurat \\
\hline 38 & Bahasa & $\begin{array}{l}\text { Bahasa } \\
\text { nan... }\end{array}$ & 79 & 813 & Akurst. & Akurst \\
\hline 39 & IPS & $\mathrm{IPA}$ & 70,7 & 22,0 & Akurst & Akurst \\
\hline 40 & IPS & Bahasa & 775 & 69.5 & Tid sk Aku rst & Akurst: \\
\hline 41 . & $\mathrm{IPA}$ & $\mathrm{IPA}$ & 755 & 743 & Akurat & Tidsk Akurat \\
\hline 42 & IPS & IPS & 74,8 & 753 & Tidak Akurat & Akurat \\
\hline
\end{tabular}
hasil peminatan yang dilakukan oleh algoritma FCM dapat dilihat pada Gambar 12 yang disajikan sebagai berikut.
Gambar 12. Akurasi hasil peminatan

Hasil peminatan yang dilakukan oleh algoritma Fuzzy C-Means (FCM) dapat dijelaskan bahwa pada tahun pertama pelaksanaan peminatan (kelas XI), sebanyak 33 dari 42 data sampel 
siswa atau 78,6\% yang tepat dalam memilih peminatan. Pada tahun kedua pelaksanaan peminatan (kelas XII), sebanyak 32 dari 42 data sampel siswa atau $76,2 \%$ yang tepat dalam memilih peminatan.

\section{PENUTUP}

Dari hasil penelitian, dapat disimpulkan bahwa:

1. Metode klastering K-Means kurang tepat digunakan untuk mengelompokkan siswa berdasarkan kesamaan kemampuan akademik dalam proses penjurusan menurut ketentuan Departemen Pendidikan Nasional. Dari 42 sampel data siswa kelas X SMA Negeri 13 Banjarmasin yang akan dikelompokkan dalam 3 kelompok berdasarkan kesamaan nilai 10 mata pelajaran inti penjurusan, diperoleh hasil:

a) Pada klaster 1, hanya ada 7 dari 9 siswa hasil klaster K-Means yang sesuai dengan hasil klaster Manual (siswa nomor 11, 17, 19, 22, 23, 27 dan 28)

b) Pada klaster 2, hanya ada 5 dari 11 siswa hasil klaster K-Means yang sesuai dengan hasil klaster Manual ( siswa nomor 4, 10, $14,16,26$ )

c) Pada klaster 3, hanya ada 8 dari 10 siswa hasil klaster K-Means sesuai dengan hasil klaster Manual (siswa nomor 5, 6, 12, 13, $15,21,25,30)$

2. Perbedaan hasil pengklasteran data siswa secara manual (berdasarkan ketentuan yang di gunakan di SMA 13 Banjarmasin) dengan hasil pengklasteran algoritma K-Means disebabkan karena:

a) Algoritma K-Means melakukan pengklasteran data siswa berdasarkan kemiripan pola data (nilai) dalam kelompok-kelompok yang yang telah ditetapkan, dan tidak terikat pada suatu aturan atau nilai-nilai variabel tertentu.

b) Metode pengklasteran siswa yang digunakan di SMA 13 Banjarmasin dalam penjurusan adalah mengelompokkan siswa berdasarkan kesamaan nilai dalam kelompok-kelompok yang telah ditetapkan, tetapi terikat pada suatu aturan atau nilai variabel tertentu, yaitu nilai standar minimum (nilai Kriteria Ketuntasan
Minimum / KKM) untuk masuk pada kelompok tertentu.

\section{REFERENSI}

[1] Departemen Pendidikan Nasional (2004), Panduan Penilaian Penjurusan Kenaikan Kelas dan Pindah Sekolah, Direktorat Pendidikan Menengah Umum, Jakarta

[2] Giyanto, Heribertus (2008), Penerapan Algoritma Clustering K-Medoid dan GathGeva untuk Penjurusan Siswa SMA Studi Kasus : Penjurusan Siswa SMAK Marsudi Luhur Yogyakarta ", Tesis, Program Studi Ilmu Komputer, Universitas Gadja Mada, Yogyakarta.

[3] Afivi, Refcan (2005), Pengelompokkan Selari Untuk Data Skala Besar dan Dimensional Tinggi Pada Aplikasi Perlombongan Data, Proceedings of the Postgraduate Annual Research Seminar, Faculty of Computer Science and Information System, Universiti Teknologi Malaysia, Malaysia.

[4]. MacQueen, J. B. (1967). Some Methods for classification and Analysis of Multivariate Observations, Proceedings of 5-th Berkeley Symposium on Mathematical Statistics and Probability, Berkeley, University of California Press, 1: 281-297.

[5] Andayani, Sri (2008), Pembentukan cluster dalam Knowledge Discovery in Database dengan Anlgoritma K-Means, MIPA, UNY (Proceding)

[6] Kusumadewi,S., Rismawan,T. (2008), Aplikasi K-Means Untuk Pengelompokkan Mahasiswa Berdasarkan Nilai Body Mass Index (BMI) dan Ukuran Kerangka, Proceedings pada Seminar Nasional Aplikasi Teknologi Informasi 2008, Jurusan Teknik Informatika, UII, Yogyakarta.

[7] Andika B.P. (2008), Verifikasi Citra Sidik Jari Poin Minutiae Dalam Visum Et Repertum (VER) Menggunakan K-Means Clustering, Jurnal Ilmu Komputer YB, Vol.XX No. XX, Universitas Brawijaya, Malang

[8) Sutikyo, P.H.P. (2009). Penggolongan Suara Berdasarkan Usia Dengan 


$\begin{array}{lcr}\text { Menggunakan } & \text { Metode } & \text { K-Means, } \\ \text { Proceedings } & \text { Jurusan } & \text { Teknik } \\ \text { Telekomunikasi, } & \text { Institut } & \text { Teknologi } \\ \text { Sepuluh NoPember, Surabaya. } & \end{array}$

[9] Dunham, Margaret,H. (2003), Data Mining Introuctory and Advanced Topics, New Jersey, Prentice Hall.

[10] Kantardzic, Mehmed (2003), Data Mining Concepts Models, Methods, and Algorithms, New Jersey, IEEE

[11] Santoso, Budi (2007), Data Mining Teknik Pemanfaatan Data Untuk Keperluan Bisnis, Graha Ilmu, Yogyakarta.

[12] Soelaiman, R., Purwitasari, D. (2005), Pengembangan Sistem Pengenalan Wajah Dengan Metode Pengklasifikasian Hibrid Berbasis Jaringan Fungsi Basis Radial dan Pohon Keputusan Induktif, Jurnal Informatika Vol. 6 No.2, Jurusan Teknik Informatika, ITS, Surabaya.

[13] Departemen Pendidikan Nasional (2006), Panduan Penyusunan Laporan Hasil Belajar Peserta Didik Sekolah Menengah Atas (SMA), Direktorat Jenderal Manajemen Pendidikan Dasar Dan Menengah Direktorat Pembinaan SMA, Jakarta 2006. 